\title{
The Impact of Terrorism on the Economic Sustainable Tourism Development of the Island of Crete
}

\begin{abstract}
By Sakina Boulal ${ }^{*}$
Terrorism is a significant threat to the tourism and travel industry, a major sector of the Greek economy contributing 18\% of the overall GDP and employing nearly one million people. The purpose of this paper is to identify the impacts of terrorism on economic Greek sustainable tourism development, especially on the Greek island of Crete, the largest island in the Mediterranean. Political, safety and security issues have adversely affected tourism in competing Mediterranean countries such as Turkey and France. The impact of this on Greek tourism economic development is investigated. This paper provides an analysis of how terrorism in competing Mediterranean countries affects development of sustainable tourism development and can facilitate economic growth in Greece while overcoming the economic crisis. The methodology employed is based on case study analysis focusing on Crete, the country's most recognized touristic island famous both for exceptional beaches and cultural significance. Statistics collected within the last 3 years and contributing to the study are based on interviews and an online survey of people working in tourism and hospitality industries. Analysis supports the conclusion that terrorism adversely affecting France and Turkey will have a positive effect on the economic sustainability of tourism in Crete.
\end{abstract}

Keywords: hospitality, sustainable tourism development, economy, Crete Island, terrorism

Much conjecture continues on the impact of terrorism on the economic sustainability of increased tourism development in Crete. It is an unfortunate fact of the $21^{\text {st }}$ century that deadly terrorism continues to plague nations where tourism is one of the major sources of their economy, as exemplified by both France and Turkey who continue losing this income because of tragic terrorist attacks (Alderman 2016). The outcome of this fact contributes to what is described as "the new dynamics of the twenty-first century... [leading] to a new competitive environment in the field of tourism and hospitality business. This scenario is driving the industry companies to adopt new strategic marketing options and operational marketing processes" (Gustavo 2013:13). The impact of successful and sustainable tourism on a nation's economy connects to several factors. Among the benefits of tourism for a nation's economy is the increased tax revenue, reduction in unemployment, and creation of a diversified economy base. Experts at "Travel \& Tourism" report on the impact of terrorism on both the economic and social development of a nation because of how it poses an enormous threat (World Travel \& Tourism Council 2015). The impact of the

\footnotetext{
${ }^{*}$ Hospitality Trainer, Oman Tourism College, Muscat, Oman.
} 
tourism industry on local, regional, and national economies is inarguably a legitimate factor.

The tourism sector is an important source of growth and employment generation, which explains the increasingly noted efforts to offer quality services to attract a larger volume of visitors. Currently, tourism is a key activity sector of socioeconomic progress, encouraging authorities to integrate strategies that ... (favor) the excellence of the services offered in their development policies and to engage in competition related to image, safety, health, infrastructure, and the environment, among other factors (Marti \& Puertas 2017:131).

The crisis of terrorism affecting European nations' tourism has significant implications for the potential of developing sustainable tourism in places like Crete. Exploration of the benefits of changing tourism patterns due to consumers looking to other destinations as a direct result of terrorist activities in formerly popular tourist destinations is an underpinning of the following study. This includes the recent violence in both Paris and Turkey and how this affects increasing tourism industry growth on Crete.

\section{The Aim of the Study}

The focus of this thesis is to find what, if any, effect terrorism has on tourism. Although several papers have previously studied this relationship (Baker 2014, Sandler \& Enders 2008, De Waal 2016, Thomas 2008, Tello 2016, Lutz \& Lutz 2006, Larobina \& Pate 2009, Kabukuru 2014, Hellenic Republic 2017, and Moss et al 2007) this research will further explore the differential effect terrorism has on tourism between developed and developing countries. The following section gives a brief overview of terrorism before its economic effect on the tourism industry is discussed in the literature review section. The methodology of this research includes meta-analysis of the existing literature and an interview/ questionnaire of tourist industry professionals for their feedback on this vital issue affecting the sustainability of tourism in Crete.

\section{Terrorism}

The origin of the word terrorism goes back to 1789 with the French Revolution (Berg 2004, Stephens 2004). Schmid and Jongman (1988:5) have defined terrorism as:

An anxiety-inspiring method of repeated violent action, employed by a (semi-) clandestine individual, group or state actors, for idiosyncratic, criminal or political reasons, whereby - in contrast to assassination - the direct targets of violence are not the main targets. The immediate human 
victims of violence are generally chosen randomly (targets of opportunity) or selectively (representative or symbolic targets) from a target population, and serve as message generators. Threat and violence-based communication processes between terrorist (organization), (imperiled) victims, and main targets are used to manipulate the main target (audience(s)), turning it into a target of terror, a target of demands, or a target of attention, depending on what the intimidation, coercion, or propaganda is primarily sought.

As described by Sandler and Enders (2008), the premeditated threat or use of violence either by individuals or by subnational groups with the purpose of gaining a social or political objective is the hallmark of terrorism. The further intention is to intimidate the larger audience beyond the immediate victims of the violence. While the motives of terrorists may differ, the actions they perpetrate follow a standard pattern of destruction of life, property, and peace. This may take form in different activities including kidnappings, assassinations, threats, bombings, hijacking airplanes, public transportation, and suicide attacks. The intention of each of these types of terrorist activities is to successfully apply enough pressure on governments resulting in granting political concessions to the terrorist or group of terrorists. As stated by Korstanje and Skoll (2013), terrorism is political violence that affects a targeted audience to reach objectives and beliefs of the organization in order to improve their power situation. This culminates with the beleaguered government deciding the anticipated costs of future terrorist actions are greater than the costs of conceding to terrorist demands. Reaching such a decision finds the government making specific accommodations.

In the case of the types of terrorism, the distinction is important when calculating the economic impact on a nation. As explained by Sandler and Enders (2008), it is important to understand the distinction that exists between domestic and transnational terrorism when determining the correct data in calculating the economic consequences of terrorism on any national setting. There is a great difference when a nation is plagued by both domestic and transnational terrorism. All forms of terrorism are included in the terrorism measure on the right-hand side of the equation. If, however, one is interested in the impact of terrorism on a host country's net foreign direct investment (NFDI), then transnational terrorist attacks are most germane, since these attacks "pose a more direct risk on foreign investors' interests" (Sandler \& Enders 2008:6-7).

The connection of such information to this study looks at how international terrorism affects travelers' decisions to visit new destinations in safer locales, as well as the historical value of visiting Greece - especially the island of Crete. Thomas (2008) explains an example of such decision-making: "A higher number of terrorist attacks in Israel ... [results] in an increase in tourists to Greece... [and the] intensity of terrorist attacks affect[s] tourist decisions" (p. 11). The relationship of terrorism and tourism is complicated and has no specific theory (Korstanje \& Clayton 2012, Korstanje \& Skoll 2012, 2013). These are factors when considering the future growth and sustainability of the already healthy presence of tourism on Crete today. 


\section{Background of the Study}

The increase in the number of beds along the coast of Crete has prodded tourism development in this region explains Andriotis (2011). This marketing ploy superseded any effort to attract tourists by attempting to provide the traveler with both diversified products and services according to their desires and needs. Consequently, this "policy-making [reveals] today the island of Crete is visited mainly by low spending mass tourists concentrated in space and time" (Andriotis 2011:93). Furthermore, the outcome shows a concentration of the population of Crete living on the north coast as well as coastal resorts because most of the island's tourist enterprises exist in these two areas. Andriotis (2011) found that tourists visiting Crete were more likely to be elderly and either semiretired or retired among those staying in Heraklion. Nearly half were visiting from the U.S. where they were city dwellers with higher education backgrounds. They vacationed with spouses or partners and their visit to Crete was primarily one motivated by anticipated educational and cultural activities. Andriotis (2011) suggests, “... these individuals were culture- oriented, they may provide a good market for the city of Heraklion to position itself as a cultural destination, under the condition that investment of funds for the development and promotion of the heritage and historic sites is undertaken" ( $p$. 93). He says further:

Heraklion is Crete's largest city and administrative center. Built by the sea, the city is the most important commercial port of the island offering to tourists a very good nightlife and many interesting sites to see such as the archaeological museum, the famous Minoan Palace at Knossos, a castle, Venetian buildings, and Byzantine churches. The city's international airport accepts the ... (majority) of charter tourists arriving on the island (nearly $80 \%$ ). In total, the city has 28 hotels with a capacity of 2,652 beds. Although the city is the largest business and commercial centre of the island and attracts ... (many) businessmen, the majority of beds (45\%) are addressed to the low budget segment (Andriotis 2011:93).

Tretheway and Mak (2006) forecast a need for Heraklion to manage its infrastructure as aligned to the steady increase in elderly tourists visiting the island city. This would mean focusing on providing "... comfortable accommodation, transportation and shopping facilities for senior tourists" (as cited in Andriotis 2011:93). On the other hand, this study found different tourist demographics in the rural Archanes area of Crete:

Archanes tended to be younger, highly educated, in full time employment and affluent, and the majority originated from the Netherlands. They were residing in a city, and were visiting the destination with their spouse or partner in order to relax and experience the nature, culture, Greek life and local food of the quiet and peaceful village. Since these tourists exhibited a higher exploratory behaviour and avoided organized tours in order to attract 
this market segment, the destination has to offer targeted products that emphasize the exploration aspects of the vacation and the environmental and cultural resources of the place. At the destination level, these tourists do not necessarily require large scale facilities. Instead, smaller traditional facilities can be offered to support the local economy (Andriotis 2011: 93).

Profiling tourists visiting Crete's coastal location of Amoudara, Andriotis (2011) found they were typically the least educated, resided in towns, and, though the majority were employed full time, they tended to have a lower income. Visiting Crete with the family included their children through package tours. The good weather under the sun and taking advantage of entertainment opportunities motivated this type of Cretan tourist. As a result, they preferred passive type of activities such as sunbathing, going out and drinking. According to past research, (Andriotis 2008, Hills and Lundgren 1977) this type of tourist looks for packages that get them accommodation in large self-contained hotels, while spending little if any time outside their resort location (as cited in Andriotis 2011: 93).

Amoudara is one of the coastal resorts of the island located just $6 \mathrm{~km}$ from the city of Heraklion. It presents the common features found in most mature seaside resorts attracting mass organised tourism. Its $7 \mathrm{~km}$ long sandy beach is very well-organized with various types of accommodation establishments, a great selection of shops, beach bars, restaurants, umbrellas to rent and many water sports. In total, it has approximately 110 accommodation establishments with approximately 3,600 beds, of which 60 percent are in hotels and the remaining in rented rooms and apartments enterprises (Andriotis 2011:93).

McKercher \& Wong (2011) describe how tourist destinations vary depending on their needs and desires resulting in the consumption of places in a different way. Variations in tourist behavior show their choice of destination is geared toward specific attributes (as cited in Andriotis 2011:93). Other studies explain that tourists' destinations and the choices they make connect to coastal, urban, and rural settings. The authors of these studies found that tourists visit cities because of the multiple functions they provide culturally, including sports activities as well as amusement products and shopping opportunities (Suh and Gartner 2004, cited in Andriotis 2011:93). Further, findings of research by Dernoi (1991) and Opermann (1996), (as cited in Andriotis 2011:93), showed rural locations as tourist destinations because of their smaller facilities, unspoiled natural settings, and rural culture. The coastal resorts draw tourists because of the three S's: sun, sea and sex (Andriotis, Agiomirgianakis and Mihiotis 2007, as cited in Andriotis 2011:93).

Andriotis (2011) found that to understand 'tourists' preferences and behaviour, researchers have widely used various socio-demographic, geographic and travel-related variables" (p. 93). The author explains that while he found "comparative research on variations in the type of destinations and tourists' 
behavior, [which] can direct destination managers to erroneous marketing and planning decisions, [it was his] ... review of past research (that) provides only a limited understanding of why tourist segments choose specific destinations and respond to each different destination the way they do" (Andriotis 2011:93). Nonetheless, Hampton and Christensen's (2007) research findings explain that although mass tourism plays a significant role in the economies of most island destinations, new market trends have emerged reducing the importance of this segment of the market. In addition, Poon (1998) describes how both the interests and values of the modern tourist have changed resulting in the emergence of new kinds of tourists (as cited in Andriotis 2011:93). Consequently, there emerges a resistance to "the homogenizing of coastal resorts and reject[ion of] inauthentic products developed for mass ... [organized] tourism" (Gale 2005, Sedmak and Mihalic 2008, cited in Andriotis 2011:93).

According to such studies of Bardolet and Sheldon (2008), Bargeman and van der Poel (2006), and Sedmak and Mihalic (2008), "modern tourists are more experienced and express increased interest in previously neglected rural and urban destinations" (as cited in Andriotis 2011:93). As a result, these changes occurring in tourists' preferences show a switch from them demanding reservations at the classical seaside resorts (Sedmak \& Mihalic 2008, cited in Andriotis 2011:93). He goes on:

Thus, it seems necessary to provide detailed information on the different attributes that tourists demand from different locations within an island. By conducting studies which enable destination managers and marketers to understand tourist demand it will become possible to provide alternatives to tourists, which perceive and wish to use the insular space in different ways, by designing products that appeal to a more diversified clientele. (Andriotis 2011:93)

Crete is among the many Greek island destinations for tourists attracting thousands of visitors every summer typically from Western Europe. Annually, tourists visiting Crete number 2.8 million. This is over 35 percent of the national total (Hellenic National Tourism Organization, 2008 as cited in Andriotis 2011:93). "The island has remarkable natural, cultural and historical resources" (Andriotis 2002, as cited in Andriotis 2011:93). In addition, Andriotis (2011) offers that, "Although in the past these tourists combined their visit with culture and nature, nowadays experiencing the cultural and the environmental resources of the island is not always a priority. Today, swimming in the crystal Mediterranean Sea, sunbathing, drinking beer, wine or ouzo, and having fun in a night club are among the main activities of incoming tourists" (p. 93). The case study of Crete and its tourism is important because the island is ideal for advancing sustainability of its economy through advancing its tourist trade. More is discussed on the impact of other nations' terrorist activity and whether the implications look at it significantly increasing tourism in Greece specific to the Island of Crete. Other factors emerge about terrorism and tourism in the following literature review section. 


\section{Literature Review}

Focusing on the feasibility of the Island of Crete, Greece becoming a sustainable tourist destination taking hold because of the realities of potential terrorism taking place at former tourist destinations will underpin the following literature review. This potential looks at the "feelings of insecurity and volatility (that) have altered people's lifestyle and encourage short-term perspectives rather than the traditional long-term perspective (Taylor \& Chesworth 2005 as cited in Gustavo 2013:13)". Further to Gustavo (2013), who describes how, "The private market tends to develop thanks to a growing number of companies that, facing no barriers and resulting from such liberalization, tend to compete in different markets on a global level (p. 13)". The center of new tourist markets emerging while old tourist markets that are now active centers of terrorist attacks are now demonstrably receding (Larobina \& Pate 2009, Kabukuru 2014, Lutz \& Lutz 2006, Tello 2016) considers the tourist perception of "proximity to self'... (As) related to judgements of risks in a systematic way (Larsen \& Brun 2011:275)". The literature review begins by explaining the relationship of terrorism and tourism followed by other considerations including the tourists' perception of safety and risk in choosing travel destinations. This and the other areas of the literature review all provide a foundation for assessing the feasibility of the economic sustainability of further developing tourism on the Isle of Crete. With the safety factor underpinning the decision making for tourist destinations it is a pertinent component in considering its dynamics on Crete as a viable alternative for a vacation destination. The different factors affecting tourists' safety perception and risk factors in choosing destinations depend on different variables.

\section{The Relationship of Terrorism and Tourism}

Some of the research explored for this scholastic work gets to the heart of the vulnerability of tourists and their safety. This is a causal factor upon which the relationship of terrorism and tourism is founded. As one research finding provides:

Tourists are not only especially vulnerable; they often have a reduced capacity to react or respond to threats or danger. There are ... (numbers of) reasons for this phenomenon. The tourist is in unfamiliar territory and among strangers. Language and knowledge of local customs and ... (behaviors) of local systems and networks of assistance can all be barriers to accessing aid. Or, as in Yemen, there may be limitations on the availability of law enforcement to respond. In some countries, tourists may ... (seem like) aliens or even 'the enemy' and in recent weeks (October/November 2001) the level of enmity toward Westerners -- particularly America and Americans -- has been forcefully expressed in many countries. Given such 
animosity, there is little wonder that Western tourists are potential candidates for kidnapping or acts of violence (Trotter 2001:59).

This results in tourist destinations serving as targets for political activists or terrorists who are intent on communicating the message of their ideology. By attacking visiting tourists rather than residents, terrorists or rebels' intentions "are less likely to alienate local support and, at the same time, is more likely to achieve public attention -- even international attention" (Trotter 2001:59). The large numbers of tourists visiting the destinations of acknowledged heritage sites are targeted as attractive to the terrorist or rebel in planning their violent attacks. "Those major sites that are visited by foreigners are doubly attractive for terrorist acts because of the fame of the site, because of the nationality of the visitors and because tourists are in a vulnerable position both physically and mentally" (Trotter 2001:59). Many of the heritage sites globally are located in remote areas, and thus are out of the mainstream tourist activities, and under the control of guides or tour leaders (Trotter 2001).

Baker (2014) explains the implications suggested by some experts and views the potential of terrorist activities as critically affecting international tourism for certain countries. The economic factor is the element underpinning the convergence of terror and foreign tourism. There is little doubt that terrorism has a punitive effect "on the flow of foreign exchange into a country because of its negative impact on international tourism" (p. 64). Pragmatically, the risk factor for tourists for some destinations can cause anxiety and affect their decision making whether to change destinations. "Different levels of risk perception together with other internal factors may determine a tourist's motivation to travel, their awareness of destination alternatives, the level of concern given to safety and terrorism threat, the extent of their information search, evaluation of alternatives, and therefore their destination choice" (Baker 2014:64).

Understandably, there are tourists who have negative attitudes toward a vacation destination directly linked to past terrorist activity. This will affect their decision in making travel plans, ending negatively for one place or another directly connected to concerns about their safety. Other factors directly affecting tourist destination decisions are media reporting about a terrorist threat or an actual event, as well as authorized tourist advisories (Baker 2014).

The effect of these outside influences on numbers of tourists' can be significant explains Baker (2014) as their imagining of specific destinations has altered considerably because of terrorist threats or activity. It is a matter of safety, especially when children are involved. Formerly, terrorist attacks as well as hijackings only affected individual tourists. However:

...we are now seeing a disturbing trend where terrorism is directed against tourists and tourist destinations. Terrorists use the tourist system to attract global media attention through spectacular attacks on tourists or the tourist infrastructure. As a result, tourists avoid these destinations, which again impacts the travel and tourism industry. The greatest impact on tourist 
demand comes from terrorist attacks where tourists and locals are the direct target or victims of the attack (Baker 2014:64).

The improvements and added sophistication exhibited by terrorists' abilities affects virtually every aspect of their sinister operations, as well as support networks. This includes the ever more aggressive use of modern technology connected to information management by terrorist groups as well as communication along with intelligence increasing the efficiency of carrying out their horrific activities. Both the availability of weapons technology and the purchasing ability of terrorists are on the rise, and the members of these groups are technologically savvy as well as trained in operating it. Ergo, the cash ready terrorist group capable of paying such skilled people who either support or are mercenary in working for the highest pay making terrorist in too many cases equal to or exceeding the governmental sophistication in counter-terrorist measures (Baker 2014).

The consensus of most experts today exhibit a belief that specific parts of the Middle East, Pakistan, Afghanistan and sub-Saharan Africa exhibit what is culminating in main power centers for terrorism. The decades of corruption and lawlessness plaguing these nations "have seen terrorist groups fill the power vacuum in these regions which continue to turn out an alarming number of motivated terrorists. Terrorists threats are increasing ... as the tourism industry continues to grow, so does the threat of terrorism and its impacts" (Baker 2014:65). The impact on terrorism's recent activities is making Europe's popular tourist destinations still reeling from the loss of income with the loss of visitors.

Alderman (2016) describes how these terrorist attacks have hit one of Europe's most vital economic sectors as the recovery from the global recession of the last decade was taking a tenuous recovery. "The shocks have come one after another: Islamic State killings of civilians in Brussels and Nice. A deadly outburst of terrorism in Germany. A terror-linked atrocity in a small French town. Warnings abound that more may be on the way" (p. 1). These terrorists' attacks substantiate how terrorist leaders are aiming to successfully compromise the economy of the regions they bring violence and death. "The political challenges for Europe's leaders are stark, and the impact on the region's economy may be just as profound" (Alderman 2016:1). Further, Alderman (2016) describes the feedback of one Paris consulting company on how the phenomenon of terrorist war tactics poses an ongoing problem to the tourist industry in the European region if not resolved.

The impact of the situation looks at "the effects of that shift on businesses, large and small, [which] have been deep. At Mont-St.-Michel, a medieval abbey that is one of France's top tourist destinations, business at the Sodetour Group, a chain of hotels and restaurants, slumped as much as 70 percent for months after the Nov. 13 terrorist attacks in Paris. It has never fully recovered" (Alderman 2016:1). Both the American and Japanese tourist cancellations of reservations are particularly high despite the location of the destination is located off the northwest coast of Normandy on an isolated rock and as significantly it is far from the horrors experienced in Paris at the hands of terrorists. Facility 
executives explained to Alderman (2016) they "had to tell nearly a third of ... (the) 230employees to go home for four months ... (while) temporarily ... (shutting) half of ... (the chains) five hotels and four restaurants" (p. 1). This culminated in the hotel chain eliminating 17 positions with new hires employed with temporary contracts. Revival of business came to a halt with the July 14, 2016 Nice massacre with cancellations jumping to 20 percent. The killing of the priest last year near Rouen located in lower Normandy brought expectations for further reservation cancellations (Alderman 2016).

Effectively hitting the tourist sector of the European economy shows that terrorist strategies are well placed. "This year, growth in the 19 countries that use the euro fell to levels not seen since the 2008 financial crisis... the European Union reported that the momentum slowed in the second quarter, as the economy advanced just 0.3 percent from April to June (of 2016), down from 0.6 percent in the previous quarter. France slid back into stagnation with zero growth in the three months to June from the previous quarter" (Aldeman 2016:1). The fact remains that this situation "may turn travelers away from Europe's largest economies and toward calmer places like Spain, Greece or Scandinavia" (Alderman 2016:1). In terms of the feasibility of Crete gaining more tourism as a sustainable aspect of its economy, the outlook is promising.

\section{Global Tourism and the Global Gross Domestic Product (GDP)}

Marti and Puertas (2017) see tourism as a field experiencing continued progress. "Despite the different circumstances of economic growth and contraction, tourism has experienced continuous progress. Blanke et al. (2009) regard it as a sector that is apparently unaffected by financial crises, changes in oil prices, and even natural disasters" (Marti \& Puertas 2017:131). The representation of global tourism continues asserting itself as a significant force in the global Gross Domestic Product (GDP). The World Tourism Organization (UNWTO) provides the latest data globally on the effect of the arrival of international tourists in 1995 where they numbered 527 million and increasing to 1,138 million in 2014. The implications of this increase suggest that countries attracting large numbers of tourists have raised their incomes in 1995 from 104,000 million dollars to 1.425 billion dollars in 2014. As a result, Marti and Puertas (2017) see, "Forecasting ... (suggesting) that this tendency will be maintained in the coming years. The UNWTO (2011) has estimated a 3.3\% annual growth rate for international tourist arrivals for the year 2030. It even suggests that arrivals at emergent destinations will double those of advanced economies (4.4\% versus $2.2 \%)$ " (p. 131).

Analysis of tourism is possible using the same manner for analyzing trade flow because it is a service industry export that significantly depends on cultural, social, and geographical factors via Marti and Puertas (2017). "Kyriakidis et al. (2009) consider that these factors not only facilitate economic growth but are also simultaneously key for the globalisation process and the expansion of commercial trade relations" (cited in Marti \& Puertas 2017:131). Marti and 
Puertas (2017) also reveal how other research focusing on identification and evaluation of tourism determinants show results with "great implications for the definition of policies adopted by authorities" (Song et al. 2012, cited in Marti and Puertas 2017:131). In addition, considering the competitiveness of tourist destinations, we must look to the multitude of empirical studies that have produced ideas for attracting tourism, advising the need for innovative strategies and tourism development connected to increasing competitiveness globally (Marti \& Puerta 2017):

According to the World Economic Forum (WEF 2011) 'competitiveness is the degree to which a nation can, under free and fair market conditions, produce goods and services that meet the test of international markets while simultaneously expanding the real incomes of their citizens at long and medium term'. By applying this definition to tourism, one may claim that a destination is competitive if it generates economic, social, and environmental benefits to the residents of the destination. Richie and Crouch (2003) dare to further delimit this idea, considering that it is the capacity to increase tourism expenditure to increasingly attract visitors by providing satisfactory experiences conducted in a beneficial way while assuring the well-being resident population and preserving the destination natural capital for future generations (Marti and Puertas 2017:131).

This includes how tourists' make decisions about their travel destinations. It is again about feeling safe. More literature regarding this concern is provided in the next section as further substantiation of the effect of terrorism in relation tourist destinations.

\section{Tourists' Perception of Safety and Risk}

The research on tourists' perception of safety and risk when choosing a holiday destination looks at the ratings provided by participating tourists about what they consider risks to themselves. In the Larsen and Brun (2011) study, they followed up on the stream of research they found that focused on the sampling of tourists who rated what they considered the risks of their destinations by selecting typical, average, and the typical tourist in their home nation.

Based on the above-cited references, we expected that risks would be judged to be higher for both the 'typical' and the 'average' tourist as compared to risks for oneself, because of their position as anonymous others. In addition, we expected that risks for the 'typical tourist from your home country', which is a closer, yet anonymous category, would be judged lower than the attributed risks for both typical and average tourists (Larsen \& Brun 2011: 275). 
From the Larsen and Brun (2011) study they found the highest risks among the participant responses linked to petty crimes and traffic accidents with the more distant perceptions of travel hazards as terrorists' activities and infectious disease. "One explanation of this may be that people generally have not had any direct knowledge of terror attacks, while many may have heard friends' and relatives' stories about accidents, or they may themselves directly have experienced such accidents or indeed have been victims of petty crime while on holiday" (Larsen \& Brun 2011:275). Further to the authors' findings they suggest this is possibly a result of previous empirical observations or even experiences that show how the variety of examples of these types of past events having distorted peoples' risk assessments so their results reveal they "judge own trips to be safer than others', ... judge distal events to be more risky and worrisome than more proximal events, and ... judge hazards to be less risky for themselves than for others" (Larsen \& Brun 2011:275). Fuentes (2015) advises from her research that, "Perceived risk, through its different dimensions, has a significant and negative effect on a destination's overall image and on a visitor's subsequent desire to return in the future" (p. 189).

Fuentes (2015) further explains how a specific dimension influences the overall perception a tourist has about a travel destination having a perceived risk that emerges in different degrees. "Some factors can mitigate perceived risk on destinations (police presence, security alarms, accessible health [centers]... and whether or not services are delivered to a tourist in his native language)" (p. 189). Risk factors as described by Fuentes (2015) look at how tourists' decision-making regarding certain destinations may be influenced by such things as: "the trip does not meet expectations, risk of damage to the environment or risk of personal image by traveling to a destination. Also, the destination, as well as a tourist's country of origin and sociodemographic characteristics, exerts a moderating effect on the perceived risk of a destination" (p. 189). Other studies (Bhat 2013) found there are five major concerns among tourism that emerge as risk factors:

Five major risks associated with tourism are terrorism; war and political instability; health risks; cultural and language difficulties; and crime. For these there is an absolute (real) and perceived (subjective) risk (Reisinger and Mavondo 2006). Every destination has to ensure the safety of tourists at any time to improve its image. Although, tourism is a major source of income for any region, many regions with highly attractive features do not achieve the high tourism rates that they warrant. This failure is mainly due to the non- manipulation of negative factors by the decision-making bodies (Bhat 2013:131).

Both security and safety remain vital to nations providing quality in tourism. In fact, Bhat (2013) views a safe and secure tourist environment as more important than any other economic activity. Further, the author's research findings note how "the success or failure of any tourism destination depends on its ability to provide safe and secure environment for its visitors" (Leiper 1990, 
Milman \& Bach 1999, cited in Bhat 2013:131). Other researchers like Ronnie and Sanette (2007) see the perception of any deficiency of personal safety as a major deterrent to both domestic and international tourists alike (cited in Bhat 2013:131).

Reisinger and Mavondo (2006) add that creating positive tourist development means understanding that what potential tourists want to perceive is how safe they will be in visiting any destination (cited in Bhat 2013:131). Numbers of scholars debate how both crime and safety problems apparent at a tourist destination negatively impact tourism demands (Pizam \& Mansfield 1996, Dimanche \& Leptic 1999, cited in Bhat 2013:131). "On the one hand, news reports magnify the danger of crime at certain destinations; on the other hand, tourists' fear might well be justified, given evidence from published research of high crime rates in tourist areas and the tendency of tourists to become victims of crime" (George 2003, cited in Bhat 2013:131). Allen (2000) and Swarbrooke (2002) advise how the perception of risk and protection by a tourist of their safety will greatly influence their intentions to travel:

When the risk makes a destination to be perceived as less safe, the potential travellers can pursue their travel plans as: change their destination choice; modify their travel behaviour; or acquire additional information if they decide to continue their travel plans (Mawby 2000, Swarbrooke 2002, Reisingere \& Mavondo 2005). Equally, political events, military actions, crime and terrorism always disrupt travel. If violence of some kind flares up in a country/region where a tourist was planning to go, he or she will most likely go somewhere else (George 2010) (Bhat 2013:131).

In addition, tourists, with past experiences where they perceived they were threatened or unsafe as explained by George (2010) are unlikely to return to the destination as well as not likely recommending the destination to others (cited in Bhat 2013:131). "This perception or reality may impact negatively on the image of the destination, seriously endangering the viability and sustainability of the industry, thereby contributing to the destruction of the tourism product" (Bhat 2013:131). A tourist destination having a competitive advantage pragmatically aligns to a dependency on perceived peace, safety, and security (Bhat 2013).

\section{Another Consideration}

Mouawad (2015) conducted an analysis of the influence of terrorist attacks on both travel and tourism. "In the hours after the terrorist attacks in Paris on Nov. 13, airlines, hotels and travel agencies witnessed a surge in cancellations as anxious visitors sought to avoid the French capital... They also threatened one of France's most vital sectors, tourism, as Paris joined a long list of cities like London; Madrid; Beirut, Lebanon; and Mumbai, India, where terror struck indiscriminately" (p. 18). Such an assessment has significant implications especially for France, since it is considered the world's top tourist-choice 
destination according to a study of 84 million foreign visitors in 2014. This is where the tourist and travel industry sector last year represents nearly 9 percent of the France's economy as described by Mouawad (2015).

The record also shows how both Madrid and London made a rapid rebound as a foreign tourist destination after they were bombed, explains Mouawad (2015) citing a study conducted by the World Travel and Tourism Council. In the study, the group determined the average time for tourism to recover is nearly 13 months after a major terror attack on a city. This is about half of the 24 months it takes after an environmental disaster hitting a city. With terrorism emerging as a typically localized happening in one place at a time, the dynamics of tourist recovery emerge.

Other data derived from analysis of tourist travel showed flight cancellations to Paris after it was the victim of a terrorist attack took about five days with anticipated future bookings dropping to about a third when compared with the same period in the year before. This suggests the terrorist attack impacted tourism for several months. In his research Mouawad (2015) found experts revealing even though leisure travel specifically but travel in genera being a fragile aspect of tourism, nonetheless it remains resilient. The experts view the lack of leisure travel bookings after a terrorist event as more common sense than fear.

Mouawad (2015) further describes feedback of experts who share they believe even though the current tourist mood in Paris is recognizably bleak and in shock, there is still potential for a quick recovery. This is in response to the 2004 Madrid Atocha train station bombing killing 191 visitors. The pre-bombing foreign visitor numbers returned within weeks. "In London, where 52 people died in coordinated bus bombings in 2005 , there was hardly any impact on tourist arrivals in Britain, according to the trade group" (Mouawad 2015:18). At the same time, Mouawad (2015) explains how other countries are experiencing sharper declines in tourism and continue struggling to regain the tourist trade after repeated terrorist attacks aimed at foreign travelers visiting these nations.

One example is Tunisia explains Mouawad (2015). It was attacked several times in 2015 including a suicide bomber killing 22 members of the nation's presidential guard. That same year attacked the capital's Bardo Museum killing 22 people who were mostly European tourists. In the summer 38 people were massacred by a single gunman in Sousse - a popular British tourist destination. Some experts, Mouawad (2015) explains, see this as reaching the point of no return with little hope for Tunisia regaining its tourism. Egypt has also seen a huge demise in its tourism losing nearly five million annual visitors in the wake of the political turmoil of the 2010 Arab Spring revolt. Still, "still the country greets some 10 million visitors each year, many ofthem Russian, especially to beach resorts in Sharm el-Sheikh" (Mouawad 2015:18). This explains why the departure of the Russian airliner from Sharm el-Sheikh and the subsequent bombing killing all on board was a particularly difficult blow for Egyptian tourism even with the Sharm under heavy protection.

Again, the lag in tourism picking back up after countries experience natural disasters is probably because of the destruction of the nation's infrastructure. 
"After the2004 tsunami in Thailand and the 2010 earthquake in Haiti, it took from 14 to 22 months for foreign visitor levels to recover, according to the World Travel and Tourism Council study" (Mouawad 2015:18). Japan is another example:

After the 2011 tsunami and nuclear meltdown of the power plants in Fukushima, the number of foreign visitors to Japan dropped 28percent. Even so, within two years of the nuclear accident, the number of foreign arrivals had rebounded. By 2013, the number of visitors to Japan exceeded 10 million people for the first time ever, surpassing the pre-nuclear accident arrival numbers by 20percent. Thanks to a weak yen and more flexible visa policies, particularly for Asian visitors, tourists have been visiting in bigger numbers than ever. Japanese government estimates show the country had received 14.5 million visitors by September, already well ahead of last year's 13.4 million people (Mouawad 2015:18).

Similarly, consider the dynamics of the terrorist attacks September 11, 2001 striking at the United States. Five years passed before the numbers of international tourists began picking up numbers to reach the pre-9/11 levels (Mouawad 2015). "In recent years, however, efforts to streamline visa applications and entry procedures have led to a large increase in the number ofvisitors, which jumped to 75 million in 2014, up from 54 million in 2009" (Mouawad 2015: 18). He further describes how the perceived U.S. risk connects to the government overreacting to tragedy by turning back its visitor-friendly policies as it has under the new Trump administration.

\section{Findings/Results/Analysis Responses to the Questionnaire}

This study used a questionnaire (Appendix A, p. 20) to gain responses from 13 personnel working at Cretan resorts and similar facilities. They were each asked seven open-ended and closed questions. The answers for the high season of tourist activity varied between July and September. The median answers among the 13 for whether the tourism movement of 2015 and 2016 was positive, confirmed this while noting that Crete is the largest of the Greek islands and that the terrorism in both France and Turkey were key factors for choosing the island of Crete as a destination. Other answers included how there is an overall increase in tourism throughout the Mediterranean nations. The typical answer to whether Crete would be a good destination throughout the year was yes. The average response to the question of whether the terrorism in both France and Turkey had created a positive impact on tourism in Crete was yes. The majority response to whether the influx of refugees into Crete had affected the island negatively was yes. The response to the question of what was the respondent's opinion on what needed to be improved to bring tourism around the year varied, including marketing, improving the infrastructure, government investment assistance, more 
consideration of the tourist guests and how they are treated, more direct flights to Crete.

A look at Appendix B (p. 21) shows the numbers of tourists per room according to bed during the high season. In conjunction with the findings, the meta-research aligned to the literature review provided further input to assessing these outcomes. Andriotis (2011) provides:

The rationale for choosing Crete as a case, was that although the island attracts mainly the mass organized market that prefers to visit the coast, modern tourists are becoming more demanding ... and as a result the Cretan tourism industry should respond by diversifying its products. This implies that more research is required on understanding how tourists act in different settings (urban, rural and coastal) within the island ... an effort to make the most efficient use of tourism resources and facilities and provide guidelines for future recreational, leisure and infrastructural investments (p. 93).

In addition, Andriotis (2011) determined that the aim of Crete's future policymaking should focus on providing facilities within resorts, including gambling, shopping, sport, recreational, and leisure facilities. This would encourage tourists to increase their spending. Further to the analysis of the findings of the above research, there is a need for policy makers as well as entrepreneurs to be aware of individual market segment preferences as a means for solving low spending power of a destination, including Crete's incoming tourists, the seasonality of tourist arrivals as well as the regional concentration of tourism activity and the attraction of new tourists outside of the mass organized market. "In achieving this, policy-makers and entrepreneurs should be aware of the preferences of individual market segments. Only then, they will be able to design additional, or improve existing products which will attract market attention" (Andriotis 2011:93). This is directly in alignment with the questionnaire responses regarding what Crete needs to do in order to make it an economically sustainable year-round tourist destination.

Baker (2014) advises how numbers of attributes of successful tourism affect the destination locally that include "strong economic growth, increase in disposable income and leisure time, easing of travel restrictions, successful tourist promotion, and recognition by governments" (p. 64). Via the 2014 World Travel \& Tourism Council report, their forecast is that both travel and tourism over the next ten years emerges as extremely favorable as they also predict growth rates of over 4 percent annually-continued as higher than growth rates in other business sectors globally.

Capitalizing on the opportunities for this travel ... (and) tourism growth will, of course, require destinations and regional authorities, particularly those in emerging markets, to create favorable business climates for investment in the infrastructure and human resource support necessary to facilitate a successful and sustainable tourism sector. At the national level, 
governments can also do much to implement tighter security, more open visa regimes and to employ intelligent rather than punitive taxation policies. If the right steps are taken, travel \& tourism can be a true force for good. Despite tourism economic strength, terrorism and political turmoil present major challenges to the industry (Baker 2014:64).

The underlying implications of these assessments and recommendations by experts are logical for Crete to successfully develop a sustainable economic tourist base year-round. The strategy takes investment by the government and the national tourism agency.

\section{Conclusion}

The above research focused on finding what, if any, effect terrorism has on tourism. This research successfully conducted further exploration beyond the existing studies on the topic and provided the differential effect terrorism had on tourism between developed and developing countries in the past. By applying the above methodology of meta-analysis of the existing literature and successfully conducting a qualitative and quantitative interview questionnaire of 13 representatives of Crete resorts and similar tourist destinations the findings were successful in subsidizing the meta-analysis of the researched literature.

In determining the effect of terrorism on tourism, we provided relevant insights by contributing to this vital issue affecting the economics of the global community. In review of the above literature and research that offered specific data from research intended to determine the feasibility of the island of Crete achieving an economic sustainability through increased tourism resulting from terrorist activities accomplishing their violent intentions in Europe to bring down the economic benefits of tourism the above research achieved just that. The above has successfully contributed to the body of work on this critical subject in general but with the implications that align to Crete successfully achieving a sustainable increase in its economy lay in the suggestions offered in the above discussion under the findings section. At the same time, the fact that the literature presented above also provided examples of unforeseen tourist recovery after terrorist attacks in some of the major European cities suggests the importance of further research in the continued effort to keep tourism as a healthy aspect of the world economy that it has historically proven. With Crete as the example for doing so in the above, there are serious implications for successful outcomes.

\section{References}

Alderman L (2016, July 3) Attacks spook tourists Europe sorely needs. International New York Times.

Andriotis K (2011) A comparative study of visitors to urban, coastal and rural areas. Evidence from the island of Crete. European Journal of Tourism Research 4(2): 93. 
Andriotis K, Vaughan D (2004) The tourism workforce and policy: exploring the assumptions using crete as the case study. Current Issues in Tourism 7(1): 66-87.

Andriotis K (2002) Scale of hospitality firms and local economic developmentevidence from Crete. Tourism Management 23(4): 333-341. ISSN 0261-5177.

Bardolet E \& Sheldon P (2008) Tourism in archipelagos: Hawai'i and the Balearics. In Annals of Tourism Research 35(4): 900-923. ISSN 0160-7383.

Baker D (2014) The effects of terrorism on the travel and tourism industry. International Journal of Religious Tourism and Pilgrimage 2(1). Retrieved from http://arrow.dit.ie/ijrtp/vol2/iss1/.

Bargeman Poel (2006) The role of routines in the vacation decision-making process of Dutch vacationers. In Tourism Management 27(4): 707-720. ISSN 0261-5177.

Berg (2004) Terrorism: The new international challenge. Paper presented at the public workshop How Should Fiji Respond to the Threat of Terrorism? Citizens' Constitutional Forum and the Fiji Human Rights Commission, 17 July 2004, Suva, Fiji.

Bhat MA (2013) Safety and security perceptions: an empirical assessment of tourists in kashmir. Journal of Services Research 13(2): 131.

De Waal A (2016) Do not run on the platforms - if you look a bit foreign: de/constructing the travelling terrorist assemblage. Liminalities 12(5): 1.

Dimanche F, Lepetic A (1999) New Orleans tourism and crime: A case study. Journal of Travel Research 38(1):19-23.

Fuentes RC (2015) Tourist experience, image, security and cultural centres. European Journal of Tourism Research 11(189).

George R (2010) Visitor perceptions of crime-safety and attitudes towards risk: The case of table mountain National Park, Cape Town. Tourism Management 31 (6): 806-815.

Gustavo N (2013) Marketing management trends in tourism and hospitality industry: facing the 21st century environment. International Journal of Marketing Studies 5(3): 13 .

Hampton MP, Christensen J (2007) Competing industries in islands a new tourism approach. Annals of Tourism Research 34(4): 998-1020.

Hellenic Republic (2017) For a sustainable tourism industry. Retrieved from http:// www.mfa.gr/usa/en/about-greece/tourism/for-sustainable-tourism-industry.html.

Hills LT, Lundgren J (1977) The impact of tourism in the Caribbean: A methodological study. Annals of Tourism Research 4(5): 248-267. ISSN 0160-7383.

Kabukuru W (2014) Kenya Looks Inwards to Battle Tourism Crisis. African Business 410: 56.

Korstanje ME, Clayton A (2012) Tourism and terrorism: conflicts and commonalities. Worldwide Hospitality and Tourism Themes 4(1): 8-25.

Korstanje ME, Skoll G (2012) New York-Buenos Aires: different solutions to the same problem: terrorism and citizenry. Rosa Dos Ventos 4(1): 40 -58.

Korstanje ME, Skoll G (2013) Discussing concepts: terrorism and tourism in the spotlight. Turismo y Desarrollo: Revista de Investigación en Turisme y Desarrollo Local 6(14).

Larobina MD, Pate RL (2009) The impact of terrorism on business. Journal of Global Business Issues 3(1): 147.

Larsen S, Brun W (2011) 'I am not at risk - typical tourists are'! Social comparison of risk in tourists. Perspectives in Public Health 131(6):1 275.

Lutz JM, Lutz BJ (2006) International terrorism in latin america: effects on foreign investment and tourism. The Journal of Social, Political, and Economic Studies 31(3): 321. 
Marti L, Puertas R (2017) Determinants of tourist arrivals in European Mediterranean countries: analysis of competitiveness. European Journal of Tourism Research 15: 131.

Mawby RI (2000) Fear of crime among British holidaymakers. The British Journal of Criminology 40(3): 468-479.

McKercher UIC, Wong B (2011) Day tour itineraries: Searching for the balance between commercial needs and experiential desires. Tourism Management 33(6): 1360-1372. ISSN 0261-5177.

Moss SE, Ryan C, Moss J (2007) Taxes, terrorism, \& tourism: Towards a global model of situational choice. Academy of Accounting and Financial Studies Journal $11(13)$.

Mouawad J (2015, December 1). Tourism often rebounds after terrorist attacks; Analysis indicates fallout from natural disasters is more harmful in long run. International New York Times

Pizam A, Mansfeld Y (1996) Tourism, crime and international security issues. New York: Wiley.

Reisinger Y, Mavondo F (2005) Travel anxiety and intentions to travel internationally: implications of travel risk perception. Journal of Travel Research 43: 212-225.

Reisinger Y, Mavondo F (2006) Cultural differences in travel risk perception. Journal of Travel \& Tourism Marketing 20(1): 13-31.

Richie Crouch (2003) Woods Consumer psychology of tourism. Hospitality and Leisure 2.

Sandler T, Enders W (2008) Economic consequences of terrorism in developed and developing countries: an overview. Retrieved from http://www.utdallas.edu/ tms 063000/website/Econ_Consequences_ms.pdf.

Suh YK, Gartner WC (2004) Perceptions in international urban tourism: An analysis of travelers to Seoul, Korea. Journal of Travel Research 43(1): 39-45.

Sedmak M (2008) Authenticity in mature seaside resorts. Annals of Tourism Research 35(4): 1007-1031. ISSN 0160-7383.

Schmid A \& Jongman A (1988) Political Terrorism. Amsterdam: Transaction Books. Shahar, Yael. 2002. Al-Qaida's Asian Web. Papers of the International Policy Institute on Counter-Terrorism. Retrieved from http://www.ict.org.il.

Stephens T (2004) International criminal law and the response to international terrorism. University of New South Wales Law Journal 27 (2): 454.

Swarbrooke John (2002) The development and management of visitor attractions, $2^{\text {nd }}$ ed. Oxford: Butterworth-Heinemann.

Taylor D, Chesworth E (2005) Travel styles. In WF Theobald (ed) Global Tourism, $3^{\text {rd }}$ ed, 294-308. Boston: Butterworth-Heinemann. ISBN 9780750677899.

Tello JM (2016) Tourism and violence. European Journal of Tourism Research 12:228.

Thomas A. (2008) Terrorism's effect on tourism: developed vs. developing countries. Retrieved from http://bit.ly/2mazFDU.

Tretheway M, Mak D (2006) Emerging tourism markets: Ageing and developing economies. In Journal of Air Transport Management 12(1): 21-27. ISSN 09696997.

Trotter R (2001) Heritage tourism and the illusion of safety, opinion papers. Australian Journal of Hospitality Management 7(2): 59.

World Travel \& Tourism Council (2015) Travel and Tourism - Economic Impact 2015- Greece. Retrieved from http://bit.ly/2m8Ftxw.

UNWTO (World Tourism Organization) (2011) Tourism towards 2030: Global overview. Madrid: UNWTO. 


\section{APPENDIX A}

The interviews:

The type or classification of the establishment: hotel, Bed \& breakfast, home stay, restaurant, hotel apartment

Those answers are used for a research to be presented at the international conference on Tourism management in Athens, Greece.This research is about "the positive impacts of the terrorism of the neighbors' countries on the economic sustainable tourism development in Crete island" and to find the possible ways to make Crete Island as a destination around the year.

Questions:

1. How do you feel about the tourism movement last year 2015 and this year 2016 ?

2. Why you think that the tourism movement is better this year 201

3. What are the high season month of Crete island?

4. What do you think about the tourism all around the year?

5. Do you think that the terrorism in Turkey and France has positively impacted the tourism in Crete Island?

6. Why Crete island didn't get affected passively by the terrorism even do, it is receiving refugees?

7. What should be done in your opinion to improve the tourism in Crete island around the year?

\section{APPENDIX B}

\begin{tabular}{|l|c|c|c|}
\hline & 2014 & 2015 & 2016 \\
\hline January & 17.1 & 18 & 18.6 \\
\hline February & 18.7 & 20.7 & 18.8 \\
\hline March & 20.1 & 20.5 & 22.6 \\
\hline April & 21.5 & 20.5 & 22.2 \\
\hline May & 39 & 44.5 & 40.8 \\
\hline June & 59.4 & 61.7 & 57.1 \\
\hline July & 68.2 & 70.9 & 71.1 \\
\hline August & 74.5 & 74.2 & 73.9 \\
\hline September & 59.4 & 61.3 & 62.4 \\
\hline Total & 377.9 & 392.3 & 387.5 \\
\hline Average & 41.99 & 43.59 & 43.06 \\
\hline
\end{tabular}

Crete has a drop in 2015 compared to 2014 and then a slightly up in 2016 as per the statistics. 